given into the care of a responsible adult with a warning of their dangers.

Any measures which help reduce adult parasuicidal behaviour are likely to help children too. Parental distress is still the cause of most child psychiatric disorder. Child psychiatrists must work more closely with their colleagues in adult psychiatry and paediatrics in order to identify and treat parasuicidal children and their parents.

${ }^{1}$ Shaffer D. Suicide in childhood and early adolescence. $\mathcal{F}$ Child Psychol Psychiatry 1974;15:275-91.

${ }^{2}$ Lukianowicz N. Attempted suicide in children. Acta Psychiatr Scand $1968 ; 44: 415-35$

${ }^{3}$ Pfeffer CR, Conte HR, Plutchik R, Jerrett I. Suicidal behaviour in latency-age children, an outpatient population. I Am Acad Child Psychiatry 1980;19:703-10.

${ }^{4}$ Kreitman N, Philip AE, Greer S, Bagley CR. Parasuicide. Br 7 Psychiatry $1969 ; 115: 746-7$.

5 McIntire MS, Angle CR. "Suicide" as seen in poison control centres. Pediatrics $1971 ; 48: 914-22$.

${ }^{6}$ Eisenberg L. Adolescent suicide: on taking arms against a sea of troubles. Pediatrics $1980 ; 66: 315-20$.

' Holding TA, Buglass D, Duffy JC, Kreitman N. Parasuicide in Edinburgh -a seven-year review. Br $\mathcal{F}$ Psychiatry 1977;130:534-43.

8 Otto U. Suicidal acts by children and adolescents. A follow-up study. Acta Psychiatr Scand 1972;233, suppl:5-23.

- Pfeffer CR, Conte HR, Plutchik R, Jerrett I. Suicidal behaviour in latencyage children-an empirical study. F Am Acad Child Psychiatry 1979; 18:679-92.

10 Green AH. Self-destructive behaviour in battered children. Am f Psychiatry 1978;135:579-82.

${ }^{11}$ Henderson AS, Hartigan J, Davidson J, et al. A typology of parasuicide. Br f Psychiatry 1977;131:631-41.

12 Rutter M. Relationships between child and adult psychiatric disorders. Acta Psychiatr Scand $1972 ; 48: 3-21$.

${ }^{13}$ Graham P. Depression in pre-pubertal children. Dev Med Child Neurol $1974 ; 16: 340-9$.

${ }^{14}$ Kreitman N, Smith P, Tan E-S. Attempted suicide as language: an empirical study. Br $\mathcal{F}$ Psychiatry 1970;116:465-73.

15 Walker WL. Intentional self-injury in school age children. $\mathcal{f}$ Adolesc 1980; 3:217-28.

${ }^{16}$ Stanley EJ, Barter JT. Adolescent suicidal behaviour. Am $\mathcal{F}$ Orthopsychiatry $1970 ; 40: 87-96$

17 Newson-Smith JGB, Hirsch SR. A comparison of social workers and psychiatrists in evaluating parasuicide. Br F Psychiatry 1979;134:335-42.

${ }^{18}$ Richman J. The family therapy of attempted suicide. Fam Process 1979 18:131-42.

\section{Why treat cirrhosis?}

Cirrhosis of the liver is still relatively rare in Britain but twothirds of patients already have complications by the time they come to medical attention. ${ }^{1}$ The main features of this "decompensation" are jaundice, ascites, gastrointestinal haemorrhage, and liver failure. Each can be treated in several different ways, many of them expensive and time consuming, and a few heroic.

Fluid retention will usually respond to combinations of salt restriction, diuretics, and salt-free albumin, but the response may be slow; occasionally fluid may need to be diverted from the abdominal cavity into the general circulation by devices such as the LeVeen shunt. ${ }^{2}$ Short-term measures for gastrointestinal bleeding include trying to reverse the clotting abnormalities with vitamin $\mathrm{K}$, platelet transfusion, freshfrozen plasma, and blood transfusion. Drugs such as cimeti- dine, pitressin, and more recently propranolol ${ }^{3}$ have been used in attempts to prevent or control bleeding. If it recurs the Sengstaken tube may be used, and endoscopicinjection of varices is popular at present. ${ }^{4}$ As a final resort laparotomy may be undertaken on the grounds that not all bleeding is due to varices; inevitably, operation places a heavy strain on a patient whose liver function is already compromised. Liver failure itself may improve if a cause can be found; excessive alcohol intake, infections, anaemia, hypokalaemia, constipation, and overenthusiastic use of drugs are the most common. Otherwise the physician must rely on restriction of protein and plenty of carbohydrate and the use of lactulose or neomycin to remove the nitrogenous substances which are thought to be the cause of the encephalopathy.

All these regimens give only short-lived benefits and do not affect long-term survival. ${ }^{1}$ The treatment of ascites has made no advance in the past 50 years. Most patients with bleeding varices are dead within five. Only abstention from alcohol has any benefit-and, of course, only in alcoholic cirrhosis. Little ${ }^{5}$ has calculated the cost at 1978 figures in Australia of treating a single patient with bleeding from cirrhosis at just under A $\$ 4000$ (roughly $£ 2350$ ); if only those with a successful outcome are considered the cost is doubled, and in alcoholic cirrhosis the figure rises above $A \$ 11000$ (about $£ 6500$ ). He compares these with $A \$ 1000$ for an appendicectomy and something under A $\$ 11000$ for "worthwhile" major operations such as cardiac surgery. Though national comparisons are apt to be misleading because of the different criteria used for costing, a British team ${ }^{6}$ put a figure of about $£ 1800$ (at 1977 prices) on aortic valve replacement.

Can high costs be justified for what is essentially palliation when there are waiting lists for more cost-effective operations ? Would it be better, for example, to treat bleeding varices from cirrhosis with limited transfusion and sedation? After all, the chances of immediate survival fall dramatically once a patient has been transfused 10 units or more, ${ }^{5}$ and such quantities are not uncommonly given. This somewhat negativistic attitude will no doubt be attacked on the ground that treatment is being withheld from alcoholics because of their self-destructive urge; the answer is that the prognosis for cryptogenic cirrhosis is, if anything, worse. And there are precedents for not employing drastic therapeutic measures: Little points out that surgical textbooks used to be explicit in their instructions about patients who should not be treated. The money saved could perhaps be better used to find ways of detecting patients at risk of developing cirrhosis at a time when it may still be possible to do something.

${ }^{1}$ Saunders JB, Walters JRF, Davies P, Paton A. A 20-year prospective study of cirrhosis. $\mathrm{Br}$ Med f $1981 ; 282: 263-6$.

${ }^{2}$ LeVeen HH, Christoudias G, Ip M, Luft R, Falk G, Grosberg S. Peritoneo-venous shunting for ascites. Ann Surg 1974;180:580-90.

${ }^{3}$ Lebrec D, Nouel O, Bernuau J, Bouygues M, Rueff B, Benhamou J-P. Propranolol in prevention of recurrent gastrointestinal bleeding in cirrhotic patients. Lancet $1981 ; \mathrm{i}: 920-1$.

4 Clark AW, Macdougall BRD, Westaby D, et al. Prospective controlled trial of injection sclerotherapy in patients with cirrhosis and recent variceal haemorrhage. Lancet 1980 ;ii :552-4.

${ }^{5}$ Little JM. Surgery for the alcoholic-no easy decision. Aust NZ f Surg $1980 ; 50: 563-70$.

${ }^{6}$ Monro JL, Mollo S, Brookbanks S, Conway N, Ross JK. The cost of cardiac surgery. $\mathrm{Br} \mathrm{Med} \mathrm{f} 1978$; : $: 1684-5$. 